\title{
VISCERAL FAT, PHYSICAL FITNESS AND BIOCHEMICAL MARKERS OF BRAZILIAN MILITARY PERSONNEL
}

\author{
GORDURA VISCERAL, APTIDÃO FÍSICA EMARCADORES BIOQUIIMICOS DE MILITARES BRASILEIROS
}

Original Article

GRASA VISCERAL, APTITUD FÍSICA Y MARCADORES BIOQUÍMICOS DEMILITARES BRASILEÑOS

ARTIGo ORIGINAL

Artículo Original

Laércio Camilo Rodrigues ${ }^{1,2}$ (ID) (Physical Education and Military Science Professional)

Marcos de Sá Rego Fortes 3 (ID (Physical Education Professional) Marco Antônio Muniz Lippert ${ }^{3}$ iD (Physical Education and Military Science Professional)

Samir Ezequiel Da Rosa 2,3 (DD (Physical Education and Military Science Professional)

José Fernandes Filho² (DD (Physical Education Professional)

1. Escola de Educação Física do Exército (EsEFEx), Rio de Janeiro, RJ, Brazil.

2. Escola de Educação Física e Desportos da Universidade Federal do Rio de Janeiro (EEFD/UFRJ), Rio de Janeiro, RJ, Brazil. 3. Instituto de Pesquisa da Capacitação Física do Exército (IPCFEx), Urca, Rio de Janeiro, RJ, Brazil.

\section{Correspondence:}

Laércio Camilo Rodrigues Rua Leopoldo Miguez, 169, Apto. 305, Copacabana. Rio de Janeiro, RJ, Brasil. 22060-020. laerciocr@me.com

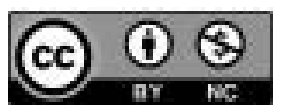

\section{ABSTRACT}

Introduction: Adipocyte volume (fat accumulation) in different parts of the body may play different roles in the metabolism and in the appearance of cardiovascular risk factors. Most studies indicate that the regional distribution of body fat seems to be more important than excess adiposity per se. High levels of physical activity are associated with lower total and visceral body fat levels. Military physical training is of paramount importance for the health and performance of soldiers in the Brazilian Army. In this context, physical evaluation will provide data on the main physical benefits involved in military tasks. Objective: Verify the relationship between visceral fat (VF), physical performance and biochemical markers of soldiers in the Brazilian Army. Methods: The sample consisted of 41 (38.9 \pm 2.2 years) Brazilian male military personnel. VF was obtained with a Dual Energy $X$-Ray Absorptiometry densitometry device. The biochemical analysis included fasting glycemia, triglycerides (TG) and HDL-C levels. Physical performance was evaluated through two tests (12-min run and pull-ups). The Shapiro-Wilk test confirmed the normality of the variables. Pearson's correlation test was then applied, with a $p$-value of $<0.05$. Results: Significant negative correlations of VF were found with the results of both physical tests (Pull-ups $r=-0.59 ; 12-\min r=-0.61$ ). The only biochemical variable that had a significant positive correlation with VF was TG $(r=0.44)$. Conclusion: The results of this study showed a significant negative association between VF and physical tests. A significant positive association between VF and TG was also found. Level of Evidence l; Diagnostic studies - Investigation of a diagnostic test.

Keywords: Intra-abdominal fat; Metabolic diseases; Physical fitness.

\section{RESUMO}

Introdução: O acúmulo de adipócitos em diferentes regiões do corpo pode desempenhar diferentes papéis no metabolismo e no aparecimento de fatores de risco cardiovascular. A maioria dos estudos aponta que a distribuição regional da gordura corporal parece ser mais importante do que o excesso de adiposidade per se. Altos níveis de atividade física estão associados a níveis mais baixos de gordura corporal total e visceral. O treinamento físico militar éde fundamental importância para a saúde e desempenho dos militares do Exército Brasileiro, neste sentido a avaliação física fornecerá dados referentes aos principais benefícios físicos envolvidos nas tarefas militares. Objetivo: Verificar a relação entre a gordura visceral (GV), o desempenho físico e os marcadores bioquímicos de militares do Exército

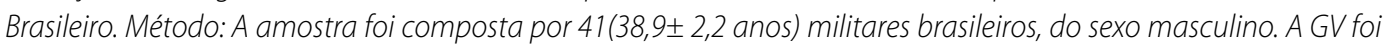
obtida através de um aparelho de densitometria "Dual Energy X-Ray Absorptiometry". A análise bioquímica incluiu as dosagens em jejum da glicemia, de triglicerídeos (TG) e HDL-C. O desempenho físico foi avaliado por meio de dois testes (corrida de 12 min e flexão de braços na barra fixa). O teste de Shapiro-Wilk confirmou a normalidade das variáveis. Na sequência foi aplicado o teste de correlação de Pearson, com valor de $p<0,05$. Resultados: Foram encontradas correlações negativas e significativas da GV, com o resultado dos dois testes físicos (Barra r = - 0,59; Teste de $12 \mathrm{~min}$ $r=-0,61)$. A única variável bioquímica que apresentou correlação positiva significativa com a GV foi TG $(r=0,44)$. Conclusão: Os resultados do presente estudo mostraram haver associação negativa significativa entre a GV e os testes físicos. Além disso, encontrou-se uma associação positiva significativa entre a GV e os TG. Nível de Evidência l; Estudos diagnósticos-Investigação de um exame para diagnóstico.

Descritores: Gordura intra-abdominal; Doenças metabólicas; Aptidão física.

\section{RESUMEN}

Introducción: La acumulación de adipocitos en diferentes regiones del cuerpo puede desempeñar papeles diferentes en el metabolismo y la aparición de factores de riesgo cardiovascular. La mayoría de los estudios indica que la distribución regional de la grasa corporal parece ser más importante que el exceso de adiposidad per se. Altos niveles de actividad física están asociados a niveles más bajos de grasa corporal total y visceral. El entrenamiento físico militar es de fundamental importancia para la salud y el desempeño de los militares del Ejército Brasileño, en este sentido la evaluación física proporcionará datos referentes a los principales beneficios físicos involucrados en las tareas militares. Objetivo: Verificar la relación entre la grasa visceral (GV), el desempeño físico y los marcadores bioquímicos de militares del Ejército Brasileño. Método: La muestra fue compuesta por 41 (38,9 2,2 años) militares brasileños, del sexo masculino. La GV fue obtenida a través de un aparato de densitometría "Dual Energy X-Ray Absorptiometry". El análisis bioquímico incluyó las dosificaciones en ayuno de glucemia, de triglicéridos (TG) y del HDL-C. El desempeño físico fue evaluado 
por medio de dos tests (carrera de 12 minutos y flexión de brazos en la barra fija). El test de Shapiro-Wilk confirmó la normalidad de las variables. A continuación, fue aplicado el test de correlación de Pearson con valor de $p<0,05$. Resultados: Se encontraron correlaciones negativas y significativas de la GV, con el resultado de los dos tests físicos (Barra r =-0,59; $12 \mathrm{~min} r=-0,61$ ). La única variable bioquímica que presentó una correlación positiva significativa con la GV fue TG $(r=0,44)$. Conclusión: Los resultados del presente estudio mostraron que hay una asociación negativa significativa entre la GV y los tests físicos. Además, se encontró una asociación positiva significativa entre GV y los TG.

\section{Nivel de evidencia l; Estudios diagnósticos-Investigación de un examen para diagnóstico.}

Descriptores: Grasa intraabdominal; Enfermedades metabólicas; Aptitud física.

\section{INTRODUCTION}

Obesity can be defined as abnormal or excessive body fat accumulation resulting from the chronic imbalance between food intake and energy expenditure, which poses serious health risks.

According to the World Health Organization (WHO), obesity is one of the top global health issues, with increasing prevalence in recent decades in various populations. ${ }^{2}$ In 2014 approximately 640 million adults were obese. ${ }^{2}$ In 2013 alone, around 4.5 million people died worldwide due to obesity. ${ }^{2}$ A recent survey by the Ministry of Health indicated that $55 \%$ of Brazilian adults are overweight and about 20\% are obese. $^{3}$

Studies conducted with Brazilian military personnel revealed data similar to the survey conducted by the Ministry of Health. In 2004, in a study involving about 3800 members of the Brazilian Army (BA), 65\% were found to be overweight and 15\% obese. ${ }^{4}$ Another more recent study, conducted in 2009, obtained similar data. ${ }^{5}$

The way adipose tissue is distributed in the body is directly related to the onset of chronic degenerative diseases. Visceral fat (VF) accumulation is the most relevant etiological factor for the development of such diseases. ${ }^{6}$

Excessive intraabdominal adipose tissue accumulation is part of a phenotype including subcutaneous adipose tissue expansion and storage of ectopic triglycerides closely related to grouped cardiometabolic risk factors.?

Several studies suggest that adipose tissue stored in various parts of the body affects metabolic health differently. ${ }^{8}$ Thus, the literature presents an adverse risk of metabolic disorder with visceral adiposity. ${ }^{9}$

Excess visceral adipose tissue is a well-established risk factor for cardiovascular disease, and small differences in its area/volume may significantly alter the risk profile. ${ }^{10}$

Waist circumference measurement is a simple and practical method for assessing VF, which is associated with increased glycemia (GLYC) and triglycerides (TG) and with decreased high-density lipoprotein cholesterol (HDL-C) levels. ${ }^{11}$

Physical activity plays a preponderant role in the prevalence of obesity. ${ }^{12}$ Studies show that it is able to improve body composition, favoring fat loss and increasing or maintaining lean tissue mass. 12,13 Thus, individuals with high levels of physical activity usually have lower levels of total body fat and VF. ${ }^{13}$ Regular physical activity also improves glucose tolerance while reducing serum TG and HDL-C levels. ${ }^{14}$

Body fat accumulation is directly related to low levels of physical fitness. ${ }^{15}$ There is a decrease in aerobic capacity with increasing relative fat. Muscle strength is also affected by body composition; individuals with higher fat percentiles have lower levels of muscle strength. ${ }^{12}$ As regards military personnel, obese and physically unfit individuals are a risk not only to themselves, but also to their fellow soldiers in a combat environment. ${ }^{6}$

In the Brazilian Army (BA) physical activity is regulated by the EB20-MC-10.350 - Military Physical Training manual. ${ }^{16}$ This manual lists the various types of physical activity that make up Military Physical Training
(MPT), which targets the development, maintenance and recovery of physical fitness and health levels necessary for combat, and for the performance of military tasks. According to its manual, MPT must be undertaken by all active military personnel, at least four times a week. ${ }^{16}$

Real-life studies have revealed that the improvement of physical fitness, also achieved through adequate muscle strength, contributes to a significant increase in combat readiness among military personnel. ${ }^{17}$ Modern warfare requires military personnel to carry out their work in very diverse scenarios and sometimes under extreme conditions. ${ }^{16}$ Reports of real-life military operations indicate that their success depends on the physical fitness of their soldiers. Physically fitter military personnel resist combat stress better. ${ }^{17}$

Thus, in order to better understand the implications of obesity on the health and physical fitness of military personnel and to provide tools for the BA to define strategies to combat overweight and obesity in the Land Force, the aim of this study was to verify the relationship between visceral fat, physical fitness and biochemical markers of members of the Brazilian Army.

\section{MATERIALS AND METHODS}

The study was made up of 41 male members of the BA with a mean age of $38+2.2$ years who were serving with the army in the city and state of Rio de Janeiro. Only volunteers were selected. Exclusion criteria ruled out the selection of military personnel who were taking medication to control GLYC, HDL-C and TC, and those with any condition or injury that would prevent them from being tested.

All the participants signed the Informed Consent Form, expressing their agreement with the research procedures. The study was approved by the Institutional Review Board of Hospital Naval Marcilio Dias, where it is registered under number: 1.551.242, CAAE [Certificate of Application for Ethical Review] no:47835615.5.0000.5256.

The first stage involved taking blood samples from the military personnel to conduct biochemical evaluations. The procedure was performed in the morning, on the premises of the Army Commando and Military Officer School, and transported in accordance with the legislation in force to the biochemical laboratory of the Instituto de Pesquisa da Capacitação Física do Exército [Army Physical Training Research Institute] (IPCFEx). Subjects were instructed to perform the tests after fasting for 12 hours, advised not to undertake high-intensity physical activity and not to drink alcohol on the day prior to the test. The three markers were processed in the automatic biochemistry analyzer model BT 3000 Plus (Wiener Lab ${ }^{\circledR}$; Rosario - SF, Argentina). Serum GLYC and TG levels were determined using the enzymatic tinder technique while serum $\mathrm{HDL}-\mathrm{C}$ levels were determined using the AA plus monophase method.

The procedures for anthropometric assessment and body composition were carried out the next day at the Health and Quality of Life Section of IPCFEx. Height and body mass of the subjects were measured using the techniques described by Fernandes Filho in 2003. ${ }^{18}$ A metal stadiometer (Personal Caprice) with $1 \mathrm{~mm}$ precision (Sanny ${ }^{\circledR}$; 
São Bernardo do (ampo - SP) was used to determine height. Body mass was measured using P150M digital scales, with 50 gram precision (Líder ${ }^{\circledR}$; Rosele, Araçatuba - SP). Once height and body mass data were obtained, these were used to calculate the Body Mass Index (BMI) of the subjects based on the ratio between body mass and height squared.

The anthropometric assessment of the military personnel was followed by a body composition evaluation and visceral fat measurement using the LUNAR IDXA Metabolic Health-2015 Dual Energy X-Ray Absorptiometry (DXA) device manufactured by GE Healthcare ${ }^{\circledR}$; United Kingdom.

On the third day, the subjects' aerobic capacity and strength were assessed by means of a 12-minute run test and pull-ups (fixed bar). Subjects were already used to taking the tests as they are part of the Physical Assessment Test, ${ }_{19}^{19}$ which all members of the BA must undertake three times a year. The tests were conducted on the same day, with a 1-hour interval between sessions. The 12-minute run test was held on an official athletics track at the Army School of Physical Education. The distances covered by each subject were measured. For the pull-ups subjects were instructed to grasp the bar with the palms of their hands facing downward (pronation), leaving a space between them equivalent to approximately their shoulder width. The exercise involved bending the arms until the subject's chin was past the bar, then straightening the arms with elbows extended and lowering the trunk. The test was conducted without a time limit.

The sample was characterized by descriptive statistics (mean \pm standard deviation, maximum and minimum values). The Shapiro-Wilk test confirmed the normality of the study variables. The Pearson correlation test was applied next, with a $p$-value $<0.05$. Data processing and statistical analysis were performed using version 10.0 of the Statistics statistical software package.

\section{RESULTS}

The results obtained in this study are shown in Table 1. The mean BMI of the sample was $29.1 \pm 3.53 \mathrm{~kg} / \mathrm{m}^{2}$. It should be noted that $70 \%$ of the subjects were overweight (BMl over $25 \mathrm{~kg} / \mathrm{m}^{2}$ ) and $31 \%$ were considered obese (BMl over $30 \mathrm{~kg} / \mathrm{m}^{2}$ ). The values of the mean biochemical variables were normal, ${ }^{20}$ yet $50 \%$ of the subjects had TG values above $100 \mathrm{mg} / \mathrm{dl}$ and HDL-C values below $40 \mathrm{mg} / \mathrm{dl}$, which constitute risk factors for their health.

Significant negativeVF correlations were found with the result of the two physical tests ( $\operatorname{Bar} r=-0.59 ; 12 \mathrm{~min} r=-0.61$ ). The only biochemical variable with significant positive correlation with VF was $T G(r=0.44)$.

\section{DISCUSSION}

The purpose of this study was to verify the relationship between visceral fat, physical performance and biochemical markers of Brazilian Army military personnel.

Table 1. Anthropometric and biochemical characteristics

\begin{tabular}{c|c|c|c}
\hline Variable & Mean \pm SD & Min & Max \\
\hline Age (years) & $38.9 \pm 2.22$ & 35 & 43 \\
\hline Height $(\mathrm{cm})$ & $177 \pm 6.39$ & 164.9 & 190 \\
\hline Body mass (kg) & $90.8 \pm 11.24$ & 71.3 & 123.9 \\
\hline BMl (kg/m²) & $29.1 \pm 3.54$ & 23.3 & 37.8 \\
\hline$\%$ of fat & $29.2 \pm 3.36$ & 18.2 & 40.4 \\
\hline Visceral fat (kg) & $1.313 \pm 0.68$ & 163 & 3014 \\
\hline GLYC (mg/dl) & $85.8 \pm 14.45$ & 58 & 136 \\
\hline TG (mg/dl) & $102.6 \pm 43.26$ & 51 & 224 \\
\hline HDL-C (mg/dl) & $42.3 \pm 8.56$ & 27 & 69 \\
\hline 12-min test (m) & $2669.7 \pm 238.46$ & 2250 & 3050 \\
\hline Pull-ups (number of repetitions) & $3.8 \pm 3.9$ & 0 & 10 \\
\hline
\end{tabular}

BMI: body mass index; GLYC: fasting glucose; TG: serum triglyceride (TG) levels; HDL-C: serum high-density lipoprotein levels.
The military personnel in question had a mean BMI value of $29.1 \pm 3.58$ $\mathrm{kg} / \mathrm{m}^{2}$ and was therefore classified as obese or overweight. ${ }^{14}$ The prevalence of overweight military personnel was $70 \%$. Similar results were obtained by other researchers, who observed the prevalence of overweight in more than $50 \%$ of the military personnel enrolled in their studies. $4,2,21$ These data suggest that the prevalence of overweight in military personnel in this age group is similar to that found in the Brazilian population. ${ }^{3}$

In this study $31 \%$ of the military personnel had BMI values above 30 $\mathrm{kg} / \mathrm{m}^{2}$, and are classified as obese. The literature recognizes that one of the weak points of the BMl is that it considers body mass as a whole, without considering body composition, which may lead to misinterpretations of the nutritional status of individuals. However, in this study, 73\% of the sample had a fat percentage above $25 \%$, and we can therefore conclude that the high prevalence of overweight and obesity is mainly due to excessive accumulation of adipose tissue.

A significant negative correlation was found between $V F$ and the result obtained in the 12-minute run test, showing that the greater the amount of VF, the shorter the distance covered. Our results are consistent with previous studies that also verified the significant negative correlation between total body fat and aerobic capacity. 12,15,22 Although these studies use total body fat, the literature shows that this data is strongly related to visceral fat. ${ }^{6}$ Similar results were obtained in a study conducted in $2012 .{ }^{23}$ The researchers noted that $V F$ is inversely related to performance in the 12-minute test, and that a decrease in VF entails a significant increase in the distance covered during the test. Thus, it would appear that the amount of VF exerts a negative influence on aerobic capacity.

The correlation between muscle strength, especially upper limb strength, and body composition has been widely recognized in military personnel. ${ }^{6,12,24,25}$ The same correlation was also confirmed in the findings of this study. Individuals with a greater amount of VF performed fewer pull-ups. The pull-up test measures muscle strength and endurance; however, it is not unanimously accepted as a valid measure of absolute muscle strength or endurance. ${ }^{26}$ During the test the individual is expected to lift his own body weight, thus, the higher the BMI, the greater the resistance. Based on this presumption, individuals with higher amounts of fat free body mass may experience more difficulties than individuals who weigh less. This does not appear to have influenced the results of this study, since the high BMI of the sample can be attributed to the high percentage of fat and the high amount of VF.

It is worth emphasizing that the pull-up test is of vital importance to the military. In combat situations military personnel must be able to lift their own body weight in order to overcome obstacles. ${ }^{16,19}$ Thus it would appear that VF also exerts a negative influence on upper limb strength.

No correlations between VF, GLYC and HDL-C were observed in this study, unlike the results reported in recent studies involving military personnel. ${ }^{27,28}$ The results of such research projects show associations between VF, GLYC and HDL-C. This suggests a different behavior in terms of VF volume and changes in GLYC and HDL-C in older military personnel. Regular physical activity is known to exert a positive influence on the variables in question, improving glucose tolerance and increasing serum HDL-C. In this particular study, the level of physical activity undertaken by the military personnel was not measured, but by law they are required to perform MPT at least three times a week. MPT could possibly explain the non-observance of correlations between VF, GLYC and HDL-C.

In contrast, a significant positive correlation was observed between TG and VF. This correlation is consistent with the results reported in previous studies. ${ }^{28,29} \mathrm{~A}$ recent study found a strong correlation between VF and TG, although the same correlation was not found between VF and subcutaneous adipose tissue. ${ }^{30}$ This discovery may indicate that $V F$ is an important variable for assessing metabolic risk behavior in military personnel. 


\section{CONCLUSIONS}

In conclusion, the considerable prevalence of overweight and obesity in military personnel in the age group considered may have a direct influence on their capacity to engage in military operations, as these conditions are related to low levels of physical fitness and the risk of developing chronic degenerative diseases. The significant negative correlations between VF, aerobic capacity and muscle strength may indicate that it is an important variable to be manipulated in order to improve the physical fitness of Brazilian Army military personnel.

All authors declare no potential conflict of interest related to this article

AUTHORS' CONTRIBUTIONS: Each author made significant individual contributions to this manuscript. LCR (0000-0002-0006-8616)*: intellectual concept of the manuscript interpretation of data, writing; MSRF (0000-0003-2038-5545)*: design, interpretation of data, and review; SER (0000-0003-3728-9859)*: design, intellectual concept of the manuscript, creation of the entire research project, data acquisition and analysis; MAML (0000-0001-5950-4228)*: data acquisition and analysis and review; JFF (0000-0002-9044-0899)*: design of the work, intellectual concept of the manuscript. All authors approved the final version of the manuscript. *ORCID (Open Researcher and Contributor ID).

\section{REFERENCES}

1. Arnold M, Leitzmann M, Freisling H, Bray F, Romieu I, Renehan A, et al. Obesity and cancer: an update of the global impact. Cancer Epidemiol. 2016;41:8-15.

2. Ng M, Fleming T, Robinson M, Thomson B, Graetz N, Margono C, et al. Global, regional, and national prevalence of overweight and obesity in children and adults during 1980-2013: a systematic analysis for the Global Burden of Disease Study 2013. Lancet. 2014;384(9945):766-81.

3. Vigitel B. Vigitel 2014: vigilância de fatores de risco e proteção para doenças crônicas por inquérito telefônico. In: SVS/ Ministério Saúde e NUPENS Universidade São Paulo. Brasília: Ministério da Saúde; 2015.

4. Martinez EC. Fatores de risco de doença aterosclerótica coronariana em militares da ativa do exército brasileiro com idade superior a 40 anos [dissertação]. Rio de Janeiro: Escola Nacional de Saúde Pública; 2004

5. Martinez EC. Atividade física, condicionamento cardiorrespiratório, estado nutricional, adipocitocinas e suas relações com fatores de risco cardiovascular em homens com idade superior a 35 anos [tese] Rio de Janeiro: Escola Nacional de Saúde Pública; 2009.

6. Friedl KE. Can you be large and not obese? The distinction between body weight, body fat, and abdominal fat in occupational standards. Diabetes Technol Ther. 2004;6(5):732-49.

7. Tchernof A, Després J-P. Pathophysiology of human visceral obesity: an update. Physiol Rev. 2013;93(1):359-404.

8. Choi SI, Chung D, Lim JS, Lee MY, Shin JY, Chung CH, et al. Relationship between Regional Body Fat Distribution and Diabetes Mellitus: 2008 to 2010 Korean National Health and Nutrition Examination Surveys. Diabetes Metab J. 2017;41(1):51-9.

9. Shimabukuro M, Kozuka C, Taira S, Yabiku K, Dagvasumberel M, Ishida M, et al. Ectopic fat deposition and global cardiometabolic risk: new paradigm in cardiovascular medicine. J Med Invest. 2013;60(1-2):1-14.

10. Nicklas BJ, Ambrosius W, Messier SP, Miller GD, Penninx BW, Loeser RF, et al. Diet-induced weight loss, exercise, and chronic inflammation in older, obese adults: a randomized controlled clinical trial. Am J Clin Nutr. 2004;79(4):544-51

11. Friedl KE. Waist circumference threshold values for type 2 diabetes risk. J Diabetes Sci Technol. 2009;3(4):761-9.

12. Mattila VM, Tallroth KAJ, Marttinen M, Pihlajamäki H. Physical fitness and performance. Body composition by DEXA and its association with physical fitness in 140 conscripts. Med Sci Sports Exerc. 2007;39(12):2242-7.

13. KohrtWM, Malley MT, Dalsky GP, Holloszy JO. Body composition of healthy sedentary and trained, young and older men and women. Med Sci Sports Exerc. 1992;24(7):832-7.

14. Associação Brasileira para o Estudo da Obesidade e da Síndrome Metabólica (ABESO). Diretrizes Brasileiras de Obesidade $2016.4^{\circ}$ ed. São Paulo: 2016
15. Santtila M, Kyröläinen H, Vasankari T, Tiainen S, Palvalin K, Häkkinen A, et al. Physical fitness profiles in young Finnish men during the years 1975-2004. Med Sci Sports Exerc. 2006;38(11):1990-4.

16. Estado-Maior do Exército. Manual de Campanha EM 20-MC-10.350 - Treinamento Físico Militar. $4^{\circ}$ ed. Brasilia: EFGC; 2015

17. O'Connor JS, Bahrke MS, Tetu RG. 1988 active Army physical fitness survey. Mil Med. 1990;155(12):579-85.

18. Fernandes Filho J. A prática da avaliação física. $2^{\circ}$ ed. Rio de Janeiro: Shape; 2003.

19. Estado-Maior do Exército. Diretriz para ao Treinamento Físico Militar e sua Avaliação. Brasilia: EGGCF; 2008.

20. Alberti KG. Harmonizing the metabolic syndrome: a joint interim statement of the International Diabete Federation Task Force on Epidemiology and Prevention; National Heart, Lung, and Blood Institute; American Heart Association; World Heart Federation; International Atherosclerosis Society; and Internationa Association for the Study of Obesity. Circulation. 2009;120(16):1640-5.

21. Neves EB. Prevalência de sobrepeso e obesidade em militares do exército brasileiro: associação com a hipertensão arterial. Ciênc Saude Colet. 2008;13(5):1661-8.

22. Croteau KA, Young CJ. Effectiveness of a Navy remedial exercise intervention. Mil Med. 2000;165(10):786-90

23. Mikkola I, Keinänen-Kiukaanniemi S, Jokelainen J, Peitso A, Härkönen P, Timonen M, et al. Aerobic performance and body composition changes during military service. Scand J Prim Health Care. 2012;30(2):95-100

24. Sharp MA, Knapik JJ, Walker LA, Burrell L, Frykman PN, Darakjy SS, et al. Physical fitness and body composition after a 9-month deployment to Afghanistan. Med Sci Sports Exerc. 2008;40(9):1687-92.

25. Vanderburgh PM. Occupational relevance and body mass bias in military physical fitness tests. Med Sci Sports Exerc. 2008;40(8):1538-45.

26. Pate RR, Burgess ML, Woods JA, Ross JG, Baumgartner T. Validity of field tests of upper body muscular strength. Res Q Exerc Sport. 1993;64(1):17-24.

27. Oliveira MA, Fagundes RL, Moreira EA, Trindade EB, Carvalho Td. Relação de indicadores antropométricos com fatores de risco para doença cardiovascular. Arq Bras Cardiol. 2010;94(4):478-85.

28. Da Rosa SE. O Treinamento Físico Militar e Fatores da Síndrome Metabólica em oficias da Escola de Comando e Estado-Maior do Exército [dissertação]. Rio de Janeiro: Universidade Federal do Rio de Janeiro; 2016

29. Rosa SE, Fernandes Filho J, Fortes MS, Chain AC, Martinez EC. Serum biochemical markers and anthropometric measurements in the Brazilian army militaries selected for the United Nations Peacekeeping Mission in Haiti. Glob J Res Anal. 2015;4(7):38-40.

30. Kwon H, Kim D, Kim JS. Body fat distribution and the risk of incident metabolic syndrome: longitudinal cohort study. Sci Rep. 2017;7(1):10955. 